\title{
Potensi Jenis Bahan Organik Sebagai Biostimulan dalam Meningkatkan Populasi Azospirillum sp, dan Hasil Kedelai (Glycine Max. L.) pada Inceptisol Jatinangor
}

\author{
Pujawati Suryatmana1), Silmi Rahadiana Putri2), Nadia Nuraniya Kamaluddin¹), \\ dan Mieke Rochimi Setiawati1)
}

1)Departemen Ilmu Tanah dan Sumberdaya Lahan, Fakultas Pertanian Universitas Padjadjaran

2) Magister Biomanajemen, Sekolah Ilmu dan Teknologi Hayati, Institut Teknologi Bandung

Korespondensi: pujawati@unpad.ac.id

\begin{abstract}
Azospirillium is a genus of non-symbiotic $N$ fixer bacteria, known as a biological fertilizer inoculant. The quality of Azospirillum sp. inoculant often decrease when applied outside its original habitat. Therefore, it is necessary to maintain the viability and increase its effectiveness. One way that can be done is by adding organic material as additives as a source of energy for bacteria. Potential organic materials can be used as additives to stimulate the viability, activity and effectiveness of Azospirillium sp. are coconut water, molasses and bran. The organic material contained elements such as $C, N$ and $P$ as the source of nutrients for Azospirillium sp. which was inoculated in Soybean (Glycine max L.) plants. This experiment aimed to examine the effect of additive application on Azospirillum sp. population, root nodules, and seed weight of soybean plants (Glycine max L.) on Jatinangor Inceptisols. The experimental design used was Randomized Block Design (RBD) consisted of combination between of Azospirillum sp. and additives type, namely molasses, coconut water and bran. The results showed that the application of a mixture of bran, molasses, and coconut water attracted the population of Azospirillum sp. higher than the control treatments. Meanwhile molasses, coconut water, and additive mixtures have the potential to increase the number of root nodules and soybean pods yields. Coconut water, molasses and bran are organic materials that have the potential as additives that stimulate the activity and increase the population of Azospirillium sp. and soybean pods.
\end{abstract}

Keywords: additives, Azospirillum sp., soybean, Inceptisol.

\section{PENDAHULUAN}

Berdasarkan data BPS (2015), produksi kedelai di Indonesia baru mencapai 963.183 Ton, jumlah ini dinilai belum memenuhi kebutuhan konsumsi kedelai penduduk Indonesia yang mencapai 2,6 - 2,7 Juta Ton per tahun. Upaya pemenuhan kebutuhan kedelai ini dilakukan dengan mengimpor komoditas tersebut dari negara-negara produsen kedelai seperti Amerika Serikat, Kanada dan Malaysia (BPS, 2019). Permasalahan yang dihadapi dalam meningkatkan produktivitas kedelai saat ini adalah masalah luas lahan yang semakin berkurang.

Salah satu ordo tanah dengan luas penyebaran yang potensial dikembangkan untuk budidaya kedelai di Indonesia yaitu tanah Inceptisol. Sebaran jenis tanah ini mencapai 70,52 juta ha (Puslittanak, 2003). Namun, jenis tanah ini memiliki permasalahan yang beragam terutama masalah kesuburan tanah. Sebagian besar Inceptisol mengandung bahan organik dan memiliki tingkat kesuburan tanah yang tergolong rendah dengan $\mathrm{pH}$ yang masam (Abdurachman dkk., 2008).

Nursyamsi dan Suprihati (2005) menyatakan bahwa penggunaan pupuk nitrogen pada Inceptisol lebih tinggi dibandingkan pada Andisol. Hal ini disebabkan karena nitrogen pada Inceptisol pada taraf tergolong rendah, sehingga diperlukan pupuk $\mathrm{N}$ yang tinggi. Oleh karena itu diperlukan metode pemupukan yang tepat untuk menghasilkan panen biomassa yang tinggi pada tanah yang memiliki tingkat kesuburan rendah. Salah satu upaya adalah dengan memanfaatkan potensi pupuk hayati untuk mengurangi kebutuhan pupuk anorganik yang digunakan.

Jenis mikroba yang potensial digunakan sebagai pupuk hayati dalam peningkatan nitrogen yaitu kelompok bakteri pemfiksasi nitrogen dari genus Azospirillum. Azospirillum sp. merupakan bakteri pemfiksasi nitrogen bebas di atmosfer dan memiliki potensi sebagai 
plant growth promoting rhizobacteria (PGPR). Jabbar dan Halimi (2012) menyatakan bahwa Azospirillum yang diberi tambahan kultur Rhizobium dapat menunjukkan pengaruh yang signifikan terhadap $\mathrm{N}$ total, pembentukan nodula, pertumbuhan dan hasil tanaman kedelai. Bashan dan de-Bashan (2002) menambahkan bahwa peningkatan penyerapan mineral pada tanaman yang diinokulasikan kemungkinan terjadi karena mekanisme pertumbuhan tanaman yang ditingkatkan oleh Azospirillum sp.

Potensi Azospirillium sp. telah banyak diteliti, namun masih terdapat kendala yang dihadapi dalam pengaplikasian Azospirillium ke dalam tanah yang bukan merupakan habitat asalnya. Permasalahan yang sering timbul adalah menurunnya viabilitas dan aktifitas metabolik dari Azospirillium sp. Daya hidup Azospirillium sp. perlu terpelihara dan bahkan perlu ditingkatkan kapasitas aktifitas sebagai bakteri pemfiksasi $\mathrm{N}$ dan PGPRnya selama diaplikasikan pada rhizosfir.

Salah satu upaya untuk meningkatkan daya hidup mikroba yaitu dengan penambahan bahan organik sebagai aditif. Bahan organik dapat digunakan untuk memelihara dan meningkatkan viabilitas sel dan aktifitas Azospirillium sp. Bahan aditif dapat diartikan sebagai bahan yang ditambahkan dalam jumlah kecil untuk memperbaiki atau meningkatkan kualitas dari suatu produk. Dalam hal ini aditif yang dimaksud adalah bahan sebagai sumber nutrisi tambahan bagi inokulan Azospirillum sp. Bahan organik yang dapat dipilih harus berfungsi sebagai aditif pemacu aktivitas mikroba dengan harga yang murah dan mudah didapat.

Bahan organik seperti air kelapa, molase dan dedak mengandung berbagai nutrisi yang dibutuhkan untuk menunjang kehidupan Azospirillum sp. Bahan-bahan tersebut diharapkan dapat meningkatkan jumlah populasi Azospirillum sp., sehingga akan menunjang proses nodula akar pada kedelai, nisbah pupus akar dan bobot biji tanaman kedelai (Glycine $\max$ L.). Menurut Stella dan Sivasakthivelan (2009) penggunaan sumber karbon seperti sukrosa dan manitol mengakibatkan peningkatan viabilitas dan aktivitas bakteri dalam pupuk hayati. Karbohidrat juga menjadi sumber karbon utama bagi Azospirillum sp, selanjutnya penggunaan lemak sebagai sumber karbon berikutnya.

Menurut Onifade dan Angola (2003), air kelapa dalam perindustrian dapat dimanfaatkan untuk meningkatkan pertumbuhan tanaman maupun sumber nutrisi bagi mikroba karena kaya akan mineral. Namun, penggunaan air kelapa dalam budidaya tanaman belum banyak dilakukan. Palungkun (2006) menyatakan bahwa air kelapa tua mengandung karbohidrat sebesar 4,6 g, 1,5 g lemak, 0,14 g protein, dan 91,5 mg air. Sedangkan dedak padi merupakan limbah beras yang mengandung energi metabolis sebesar $2.100 \mathrm{kkal} \mathrm{kg}^{-1}$, Ca 0,07\%, P tersedia 0,21\%, serta Mg 0,22\% dan kandungan nutrisi lain yaitu serat kasar 7,0$11,4 \%$, karbohidrat 34,1-52,3\%, lemak 15,0$19,7 \%$, protein $11,3-14,4 \%$ dan sejumlah kecil sumber vitamin (Nadiyah dkk., 2005). Menurut Oedjijono dkk. (2003), Azospirillum dapat berkembang pada medium yang dedak dikombinasikan dengan onggok. Kedua bahan tersebut mengandung sejumlah karbohidrat, protein dan lemak. Molase adalah produk gula tebu setelah melalui kristalisasi berulang (Paturau, 1982). Molase mempunyai kandungan gula sekitar $40 \%$ - 45\% dengan nilai $\mathrm{pH}$ 5,5 - 6,5 (Kirk dan Othmer, 1963). Selain itu, molase memiliki komposisi kimia antara lain sukrosa (30-40\%), glukosa (4-9\%), fruktosa (5-12 \%), komponen nitrogen (2-6\%), dll (Paturau, 1982). Menurut Akbari dkk. (2007) Azospirillum dapat meng-hasilkan hormon pertumbuhan hingga $285,51 \mathrm{mg} \mathrm{lt}^{-1}$ dari total medium campuran dedak.

Berdasarkan uraian di atas maka aktivitas dan viabilitas Azospirillum sp. dalam aplikasinya dengan menambahkan bahan organik sebagai aditif diharapkan dapat meningkatkan pertumbuhan dan hasil tanaman kedelai. Hasil penelitian Widawati (2015) memperlihatkan bahwa inokulasi bakteri dapat menghasilkan perbedaan nyata pada tinggi tanaman, diameter batang, berat kering akar, berat kering pupus, dan 
pemnodulaan sebagai efek dari inokulasi bakteri penambat $\mathrm{N}$ simbiotik dan nonsimbiotik pada anakan tanaman Turi (Sesbania grandiflora).

Tujuan dari penelitian ini adalah mengkaji potensi air kelapa, molase dan dedak sebagai aditif organik yang berfungsi sebagai biostimulan yang untuk meningkatkan populasi Azospirillum spp. di rizosfir, nodula akar, nisbah pupus akar dan bobot biji kedelai (Glycine max. L.).

\section{METODOLOGI}

Penelitian ini dilakukan di Lahan Percobaan Ciparanje Fakultas Pertanian, Universitas Padjadjaran, Kec. Jatinangor, Kabupaten Sumedang, Provinsi Jawa Barat, pada ketinggian \pm 774 meter di atas permukaan laut Fakultas Pertanian Universitas Padjadjaran.

\subsection{Rancangan percobaan}

Rancangan percobaan yang digunakan adalah Rancangan Acak Kelompok (RAK) yang terdiri dari 10 (sepuluh) perlakuan, yaitu:

A. Kontrol (tanpa Azospirillumsp, tanpa aditif)

B. Molase

C. Air kelapa

D. Dedak

E. Campuran (molase, air kelapa dan dedak)

F. Azospirillum sp.

G. Azospirillum sp. + Molase

H. Azospirillum sp. + Air kelapa

I. Azospirillum sp. + Dedak

J. Azospirillum sp. + campuran (molase, air kelapa dan dedak)

\subsection{Persiapan Media Tanah dan Perbanyakan Isolat Azospirillum sp.}

Persiapan media tanam dilakukan dengan cara menyiapkan polybag berukuran tinggi 40 $\mathrm{cm}$ dengan diameter $30 \mathrm{~cm}$ yang sudah diberi lubang di bagian bawah. Kebutuhan media tanam untuk penanaman yaitu $8 \mathrm{~kg}$ per polibag.

Perbanyakan isolat Azospirillum sp. dilakukan dengan menginokulasikan kultur induk Azospirillium sp. dalam larutan garam
$\mathrm{NaCl}$ fisiologis $(0,85 \% \mathrm{NaCl})$ sebanyak $5 \% \mathrm{ke}$ dalam media Okon cair. Volume media Okon cair didalam reaktor 2 liter sebanyak $1.000 \mathrm{ml}$. Selanjutanya kultur Azospirillium sp. diinkubasi selama 3 hari dengan pengocokan 100 rpm pada suhu 28-30 ${ }^{\circ} \mathrm{C}$. Pada hari ke 3 kultur Azospirillium sp. dipanen yang menagndung kepadatan sel sebesar $10^{9} \mathrm{cfu} \mathrm{ml}^{-1}$. Kultur ini selnjutnya untuk digunakan sebagai perlakuan.

\subsection{Inokulasi Azospirillium sp. ke dalam aditif organik dan aplikasinya}

Air kelapa, molase dan dedak masing sebanyak $6 \%$ dicampurkan dengan $20 \mathrm{~g}$ kompos per polybag, diaduk secara homogen. Campuran kompos dan aditif diinokulasi kultur Azospirillium sp sebanyak 2,4 ml per tanaman atau dosis $5 \mathrm{~L} \mathrm{Ha}^{-1}$, dan diaduk secara homogen. Campuran tersebut selanjutnya diinkubasikan selama tiga hari, selanjutnya diaplikasikan di lubang tanam pada media tanah yang telah disiapkan dalam polybag sebelumnya. Media tanam yang sudah ditambah inokulan kemudian diinkubasi selama satu minggu, setelah itu dilakukan penanaman.

\subsection{Inokulasi Rhizobium sp, penanaman dan pemeliharaan}

Inokulasi Rhizobium sp sebagai perlakuan dasar dilakukan sebelum penanaman. Inokulasi dilakukan dengan cara merendam benih kedelai dalam suspensi Rhizobium sesuai dengan dosis. Benih kedelai kemudian langsung ditanam pada polybag.

Penanaman benih kedelai dilakukan dengan cara memasukkan satu benih kedelai pada media tanam yang telah diberi inokulan Azospirillium sp. dan aditif organik pada masing-masing polybag. Pupuk dasar yang digunakan untuk semua perlakuan adalah pupuk urea, SP-36 dan KCl. Urea yang digunakan $50 \%$ dosis anjuran. Pemeliharaan tanaman dilakukan dengan penyiraman pada pagi dan sore hari dan penyiangan gulma.

\subsection{Pengamatan dan Pemanenan}

Pengambilan sampel tanah dan tanaman untuk dianalisis dilakukan pada fase vegetatif 
maksimum dengan ciri tanaman sudah berbunga kurang lebih pada 40 hari setelah tanam (HST) dan pada saat pemanenan (92 HST). Contoh tanah diambil dengan cara membongkar polybag pada unit 1 plot percobaan untuk mengambil tanah sebanyak $500 \mathrm{~g}$ untuk kemudian dianalisis sesuai dengan parameter. Pengamatan meliputi total populasi Azospirillum sp, nisbah pupus akar, dan nodula akar. Polong dipanen pada saat umur tanaman 92 HST. Penghitungan bobot biji dilakukan dengan menggunakan timbangan analitik, penghitungan total bobot biji per tanaman.

\section{HASIL DAN PEMBAHASAN}

\subsection{Analisis Tanah Awal}

Hasil analisis awal terhadap tanah yang digunakan menunjukkan tanah memiliki kelas tekstur liat dengan kadar liat 53,8 \%, debu 40,3 $\%$ dan pasir 5,9\%. Hasil analisis terhadap unsur hara menunjukkan bahwa $\mathrm{P}_{2} \mathrm{O}_{5}$ tersedia $(2,71 \mathrm{ppm})$ dan $\mathrm{P}_{2} \mathrm{O}_{5}$ potensial $(14,27 \mathrm{mg} 100$ $\left.\mathrm{g}^{-1}\right)$ yang termasuk kriteria sangat rendah. Kandungan C-organik (1,85\%), N-total $(0,2 \%)$ dan Na-dd $\left(0,34 \mathrm{cmol} \mathrm{kg}^{-1}\right)$ termasuk kriteria rendah. Kapasitas Tukar Kation (KTK) $(21,73$ cmol $\left.\mathrm{kg}^{-1}\right)$, kejenuhan basa $(56,60 \%) \mathrm{K}$-dd $\left(0,59 \mathrm{cmol} \mathrm{kg}^{-1}\right)$ dan Ca-dd $\left(6,61 \mathrm{cmol} \mathrm{kg}^{-1}\right)$ tergolong sedang, Mg-dd (4,76 $\left.\mathrm{cmol} \mathrm{kg}^{-1}\right)$ tergolong kriteria tinggi. Tanah yang di uji juga memiliki $\mathrm{pH}_{2} \mathrm{O}$ sebesar 5,77 yang termasuk kategori agak masam. Berdasarkan hasil analisis sifat biologi tanah awal dengan menggunakan metode Total Plate Count (TPC), populasi Azospirillum sp berjumlah 12,5 x $10^{6}$ CFU g-1.

Tanah yang digunakan untuk percobaan termasuk Inseptisol asal Jatinangor dengan kandungan hara dan tingkat kesuburan yang rendah, hal ini terlihat dari kandungan Corganik serta $\mathrm{N}$-total tanah yang tergolong rendah. Oleh karena itu, diperlukan penambahan pupuk organik, pupuk hayati dan pupuk anorganik untuk meningkatkan kesuburan tanah.

\subsection{Populasi Bakteri Azospirillum spp}

Penghitungan populasi bakteri Azospirillum sp. dilakukan pada fase tanaman memasuki vegetatif akhir. Tanah yang berada di rizosfir diambil dan kemudian dilakukan penghitungan menggunakan metode TPC. Populasi Azospirillum sp pada disajikan pada Tabel 1.

Tabel 1 Populasi Azospirillum sp.

\begin{tabular}{llc}
\hline \multicolumn{1}{c}{ Perlakuan } & $\begin{array}{c}\text { Populasi } \text { Azospirillum } \\
\left(10^{6} \mathrm{cfu} \mathrm{g}^{-1} \mathrm{tanah}\right)\end{array}$ \\
\hline A & Kontrol (tanpa Azospirillum sp, Tanpa aditif) & $13,2 \mathrm{~b}$ \\
& Molase & $19,2 \mathrm{ab}$ \\
C & Air kelapa & $16,8 \mathrm{ab}$ \\
D & Dedak & $26,7 \mathrm{ab}$ \\
E & Campuran (molase,air kelapa dan dedak) & $28,8 \mathrm{a}$ \\
F & Azospirillum sp + Tanpa aditif & $23,0 \mathrm{ab}$ \\
G & Azospirillum sp + Molase & $17,7 \mathrm{ab}$ \\
H & Azospirillum sp + Air kelapa & $24,2 \mathrm{ab}$ \\
I & Azospirillum sp + Dedak & $19,7 \mathrm{ab}$ \\
J & Azospirillum sp + Campuran (molase,air kelapa dan dedak) & $15,0 \mathrm{ab}$ \\
\hline
\end{tabular}

Keterangan: Nilai rata-rata yang tidak diberi notasi huruf, tidak berpengaruh nyata berdasarkan uji F pada taraf nyata $5 \%$.

Berdasarkan hasil analisis statistik populasi Azospirillium spp. di dalam tanah percobaan adalah $12,510^{6} \mathrm{cfu} \mathrm{g}^{-1}$ tanah. Hasil anlisis data secara statistik menunjukan bahwa perlakuan tanpa Azospirillum sp + campuran (molase, air kelapa dan dedak) memberikan pengaruh yang nyata dibandingkan dengan kontrol (tanpa perlakuan). Jumlah populasi Azospirillum spp pada saat analisis tanah awal penghitungan TPC berjumlah $12,5 \times 10^{6} \mathrm{CFU}$ g1, maka dapat dikatakan bahwa terjadi peningkatan jumlah populasi Azospirillum spp 
setelah diberi perlakuan. Selain itu, perlakuan kontrol (tanpa aplikasi Azospirillum sp) tanpa aditif menghasilkan jumlah populasi yang cenderung paling rendah yaitu sebesar $13,2.10^{6} \mathrm{cfu}^{-1}$ tanah. Hal ini menunjukkan bahwa penambahan bahan aditif organik campuaran antara air kelap, molase dan dedak dapat meningkatkan jumlah populasi Azospirillum sp, secara signifikan. Hal ini disebabkan karena populasi dan aktivitas Azospirillum sp dipengaruhi oleh zat yang terkandung dalam bahan aditif campuran yang ditambahkan.

Perlakuan campuran bahan aditif (molase, air kelapa dan dedak) memungkinkan bagi mikroba, khususnya Azospirillum spp. untuk mendapatkan berbagai sumber nutrisi sehingga dapat meningkatkan jumlah populasi Azospirillum sp. Seperti yang dilaporakan Onifade dan Jeff-Agboola (2003), air kelapa sebagai sumber nutrisi bagi mikroba karena kaya akan mineral. Kandungan air kelapa tua mengandung karbohidrat sebesar 4,6 g, 1,5 g lemak, 0,14 g protein, dan 91,5 mg (Palungkun, 2006).

Komponen penyusun air kelapa antara lain mineral (4\%), gula (2\%) dan sitokinin. Kandunagn gula terdiri dari glukosa, sukrosa, dan fruktosa (Warisno, 2003). Sedangkan dedak padi menyumbangkan karbohidrat sebesar 34,1-52,3\%, protein sebesar 11,3-14,4 $\%$ dan vitamin (Nadiyah dkk., 2005) dan molase mengandung sukrosa sebesar 30-40 \%, glukosa setara 4-9\%, fruktosa sebesar 5-12\%, komponen nitrogen setara 2-6\% (Paturau, 1982). Sehingga komposisi karbohidrat dan nitrogen yang dikandung oleh ke tiga aditif organik yang digunakan ini memungkinkan dapat menyediakan sumber karbon dan nutrisi lengkap dan cukup bagi Azospirillium spp. untuk berproliferasi dan tumbuh di dalam tanah.

Perlakuan aditif secara tunggal belum menunjukkan peningkatan populasi Azospirillium sp. yang signifikan, meskipun demikian pada umumnya terjadi kecenderungan menghasilkan populasi Azospirillium sp. yang lebih tinggi dibanding perlakuan kontrol. Keadaan ini terjadi diakibatkan oleh bahan aditif yang diberikan secara mandiri belum memberikan sumber $\mathrm{C}, \mathrm{N}$ dan $\mathrm{P}$ yang lengkap dan cukup bagi pertumbuhan Azospirillium sp. di dalam tanah, sehingga terjadi persaingan terhadap sumber $\mathrm{C}, \mathrm{N}$ dan $\mathrm{P}$ yang ada, hal tersebut memungkinkan pertumbuhan populasi Azospirillium sp. tidak meningkat secara asignifikan. Diketahui pula bahwa setiap mikroba memerlukan sumber karbon yang berbeda bagi pertumbuhannya. Azospirillium sp. dapat menggunakan sumber karbon utama berupa gula dan alkohol sebagai sumber energinya (Prescott dkk., 2000). Berdasarkan karakteristik metabolisme dari Azospirillium sp. tersebut dimungkinkan bahwa penggunaan aditif secara tunggal tidak cukup menyediakan asam malat, suksinat, laktat, dan piruvat yang diperlukan Azospirillium spp. sehingga terjadi persaingan antara Azospirillium sp. indigenus dan eksogenus terhadap ketersediaan senyawa organik yang diperlukan.

\subsection{Jumlah Nodula Akar Tanaman Kedelai}

Tanaman legum kedelai secara umum bersimbiosis dengan Rizobium yaitu bakteri penambat nitrogen (N) di udara dengan membentuk nodula pada akarnya. Pengamatan jumlah nodula akar tanaman kedelai dilakukan pada fase vegetatif akhir. Jumlah nodula akar tanaman kedelai tiap perlakuan ditampilkan pada Tabel 2.

Berdasarkan hasil uji statistik (Tabel 2), perlakuan tidak berpengaruh nyata terhadap jumlah nodula akar kedelai. Akan tetapi pada perlakuan molase, dan campuran tanpa Azospirillium sp. cenderung menunjukkan jumlah nodula yang lebih tinggi dibanding kontrol meskipun belum signifikan peningkatannya. Hal ini juga dapat dilihat pada perlakuan aditif secara tunggal maupun campuran yang dikombinasikan dengan aplikasi Azospirillium sp. Kedua perlakuan tersebut cenderung menghasilkan jumlah nodula yang relatif lebih banyak dibandingkan dengan perlakuan tidak menggunkan aditif maupun kontrol. Keadaan ini menunjukkan adanya potensi aditif organik yang digunakan dalam penelitian ini dapat memacu pembentukan 
nodula akar yang lebih tinggi. Jumlah nodula tertinggi cenderung terdapat pada perlakuan
Azospirillum sp. yang dikombinasikan dengan air kelapa.

Tabel 2 Jumlah nodula akar tanaman kedelai

\begin{tabular}{clc}
\hline & \multicolumn{1}{c}{ Perlakuan } & $\begin{array}{c}\text { Jumlah Nodula } \\
\text { per tanaman }\end{array}$ \\
\hline A & Kontrol (tanpa Azospirillum sp., Tanpa aditif) & 69 \\
B & Molase & 82 \\
C & Air kelapa & 59 \\
D & Dedak & 65 \\
E & Campuran (molase,air kelapa dan dedak) & 87 \\
F & Azospirillum sp. + Tanpa aditif & 58 \\
G & Azospirillum sp. + Molase & 86 \\
H & Azospirillum sp. + Air kelapa & 88 \\
I & Azospirillum sp. + Dedak & 65 \\
J & Azospirillum sp. + Campuran molase, air kelapa, dan dedak & 85 \\
Keterangan: Nilai rata-rata yang tidak bernotasi huruf, menunjukkan tidak berbeda nyata berdasarkan
\end{tabular}

Rhizobium merupakan bakteri pemfiksasi $\mathrm{N}$ simbiotik dari golongan heterotrof, yaitu bakteri yang menggunakan sumber karbon dan energinya berasal dari senyawa-senyawa organik seperti sukrosa dan glukosa. Pada prosesnya, tanaman kacang-kacangan mengeksudasi asam amino dan senyawa organik lainnya yang berfungsi sebagai kemoatraktan (tertariknya rhizobia ke sumber senyawa kimia) dan sebagai sumber energi untuk perkembangbiakan rhizobia di rhizosfer (Soedarjo, 1997).

Sison (1977) menyatakan bahwa air kelapa mengandung berbagai jenis asam amino dan di antaranya adalahasam amino esensial, antara lain: ARG, LEU, LYS, TYR, HIS, PHE dan CYS. Kandungan asam amino pada air kelapa yang ditambahkan dapat menjadi kemoantraktan bagi rhizobia-akar. Signal pada taraf molekuler terlibat dalam proses interaksi komunikasi legumerhizobial. Ada dua macam signal yang terlibat dalam komunikasi molekuler tersebut yaitu signal yang berasal dari tanaman dan signal yang berasal dari bakteri. Oleh karena itu, perlakuan Azospirillum sp + air kelapa dapat memberikan hasil yang cenderung tertinggi.

Terdapat dua faktor yang mempe-ngaruhi proses pembentukan nodul yaitu dari mikroba Azospirillum sp. yang diinokulasikan dan kandungan asam amino dalam air kelapa yang di aplikasikan dapat membantu terjadi-nya komunikasi awal dalam pembentukan nodula. Meskipun tampak peningkatannya belum signifikan. Hal ini terjadi kemungkinan dosis dari aditif yang berasal dari air kelapa yang digunakan belum cukup untuk memacu pembentukan nodula secara signifikan, meskipun pada dosis yg digunakan sudah menunjukan potensi peningkatan jumlah nodula pada akar kedelai.

\subsection{Bobot Biji Tanaman}

Bobot biji yang dihitung yaitu total bobot biji dari satu tanaman pada setiap perlakuan. Berdasarkan hasil uji statistik menunjukkan bahwa aplikasi bahan aditif dengan Azospirillum sp. berpengaruh secara tidak nyata terhadap bobot biji tanaman kedelai. Bobot biji tiap tanaman pada variasi perlakuan ditampilkan pada (Tabel 3).

Perlakuan yang memiliki kecenderungan bobot biji tanaman lebih tinggi yaitu perlakuan penambahan Azospirillum sp. dengan kombinasi campuran aditif (molase, air kelapa dan dedak) menghasilkan bobot biji 11,15 g per tanaman. Perlakuan tersebut menghasilkan potensi hasil bobot biji sebesar 2,8 ton/ha yang sudah melebihi standar bobot biji kedelai varietas Anjasmoro pada umumnya, yaitu 2,03 ton/ha. Meskipun demikian, perlakuan yang diberikan belum memberikan hasil yang nyata. Hal ini diduga karena pada jumlah nodula juga tidak berbeda nyata pada setiap perlakuan. 
Jumlah dan aktifitas nodula dapat mempengaruhi kecukupan $\mathrm{N}$ di dalam jaringan tanaman kedelai. Hasil ini sejalan dengan jumlah nodula akibat perlakuan meningkat tetapi belum signifikan peningkatannya. Jumlah nodula tidak aktif dalam proses fiksasinya akan mempengaruhi pengisian biji, karena translokasi $\mathrm{N}$ berlangsung sangat cepat. Di sisi lain proses fiksasi $\mathrm{N}_{2}$-udara oleh Rizobium pada fase yang bersamaan sudah menunjukan penurunan aktifitas (Ray, dkk., 2005).

Tabel 3 Bobot biji tanaman

\begin{tabular}{llcc}
\hline \multicolumn{1}{c}{ Perlakuan } & $\begin{array}{c}\text { Bobot Biji } \\
\text { (g/tanaman) }\end{array}$ & $\begin{array}{c}\text { Bobot Biji } \\
\text { (ton/ha) }\end{array}$ \\
\hline A & Kontrol (tanpa aplikasi Azospirillum sp., Tanpa aditif) & 8,63 & 2,13 \\
B & Molase & 9,79 & 2,45 \\
C & Air kelapa & 8,11 & 2,03 \\
D & Dedak & 7,80 & 1,95 \\
E & Campuran (molase,air kelapa dan dedak) & 7,26 & 1,82 \\
F & Azospirillum sp. + Tanpa aditif & 4,56 & 1,14 \\
G & Azospirillum sp. + Molase & 8,99 & 2,25 \\
H & Azospirillum sp. + Air kelapa & 7,66 & 1,90 \\
I & Azospirillum sp. + Dedak & 10,79 & 2,70 \\
J & Azospirillum sp. + Campuran (molase,air kelapa dan dedak) & 11,15 & 2,80 \\
\hline
\end{tabular}

Keterangan: Nilai rata-rata yang tidak ber notasi huruf, menunjukkan tidak berbeda nyata berdasarkan uji pada taraf nyata $5 \%$.

Bobot biji tanaman yang cenderung memiliki bobot paling rendah yaitu perlakuan penambahan Azospirillum sp. tanpa aditif dengan bobot biji tanaman sebesar 4,56 $\mathrm{g} /$ tanaman. Hal ini menujukkan fenomena kendala pada inokulasi Azospirillium sp. eksogenus yaitu isolat tersebut efektifitasnya lebih rendah dari Azospirillium sp. indigenus yang sangat peka terhadap kondisi lingkungan barunya.

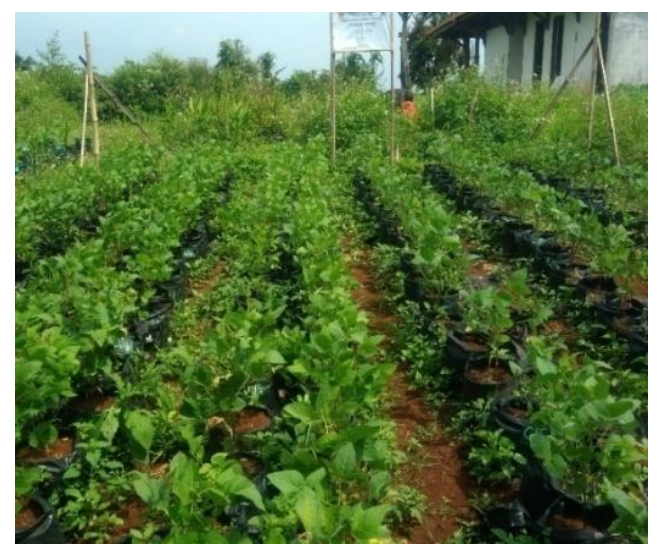

a

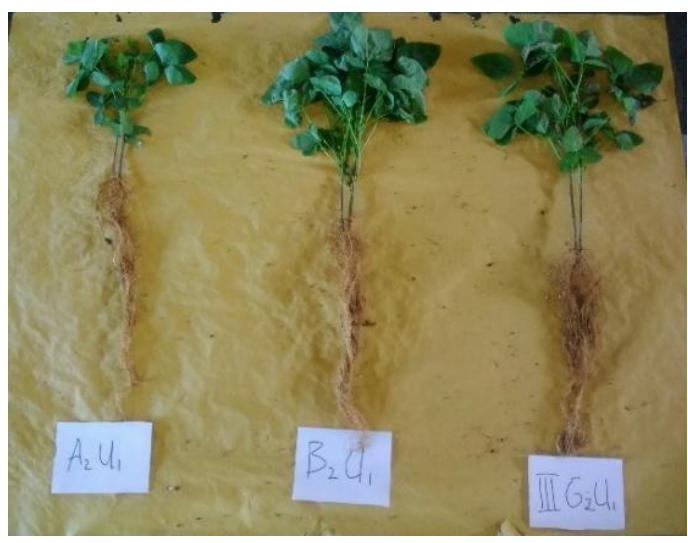

b

Gambar 1. Tanaman Kedelai pada masa vegetatif akhir (a); Perbandingan tanaman A (kontrol), B (Tanpa Azospirillum sp + Molase) dan G (Azospirillum sp. + Molase) (b).

Faktor lain yang dapat mempengaruhi aktifitas Azospirillium adalah kondisi lingkungan penting yaitu $\mathrm{pH}$ dan suhu. Suhu optimum untuk perbanyakan Azospirillum pada kisaran antara $32,0-36,0^{\circ} \mathrm{C}$, sedangkan selama penelitian suhu cenderung lebih rendah yaitu berkisar antara 23,0 - 23,4. Nilai pH optimum bagi pertumbuhan dan aktifitas 
Azospirillium spp. adalah pada kisaran antara 6,80 -7,90 (Day dan Dobereiner, 1976). Sedangkan $\mathrm{pH}$ tanah percobaan adalah 5,77. Nilai pH dan suhu yang lebih rendah dari optimum ini memungkinkan terjadinya hambatan aktifitas fiksasi N oleh Azospirillium sp yang diinokulasikan, terbukti bahwa perlakuan Azospirillium sp. tanpa aditif menghasilkan polong yang cenderung paling rendah.

\section{KESIMPULAN}

Perlakuan aplikasi campuran aditif (air kelapa, molase dan dedak) sebanyak 6\% per berat kompos sebagai bahan pembawa menghasilkan populasi Azospirillium spp. lebih tinggi secara signifikan dibanding perlakuan kontrol. Namun secara umum penambahan aditif baik tunggal maupun campuran cenderung meningkatkan populasi Azospirillium spp. Aplikasi Azospirillium sp dan aditif belum dapat meningkatkan nodula secara signifikan, akan tetapi akibat aplikasi air kelapa, molase dan campuran aditif cenderung berpotensi menghasilkan pembentukan nodula yang lebih tinggi.

Aplikasi molase, dedak dan aditif campuran memiliki potensi untuk meningkatkan hasil polong, yaitu berat polong cenderung lebih tinggi dibandikan dengan perlakuan kontrol (aplikasi pupuk kimia dengan urea 50\% dosis anjuran). Isolat Azospirillium sp. yang diinokulasikan mengalami kendala dalam beradaptasi dengan lingkungan baru dan menurunkan aktifitasnya sehingga efek terhadap hasil polong lebih rendah dari pada efektifitas Azospirillium indigenus. Hal ini ditunjukan dengan hasil polong yang lebih rendah. Akan tetapi Azospirillium sp. yang dikombinasikan dengan aditif cenderung meningkat efektifitas dan viabilitas Azospirillium spp di dalam tanah. Dengan demikian air kelapa, Molase dan dedak merupakan bahan organik berpotensial sebagai aditif biostimulan untuk meningkatkan viabilitas, aktifitas dan efektifitas inoulan Azospirillium sp. yang digunakan dalam penelitian ini.

\section{DAFTAR PUSTAKA}

Abdurachman, A., A. Dariah, Mulyani, A. 2008. Strategi dan teknologi pengelolaan lahan kering mendukung pengadaan pangan nasional. Jurnal Litbang: 27(2): $43-49$.

Akbari, G., S.M. Arab, H.A. Alikhani, I. Allahdadi, M.H. Arzanesh. 2007. Isolation and selection of indigenous Azospirillum spp. and the IAA of superior strains effect on wheat roots. World J. Agric Sci. 3(4): 523-529.

Badan Pusat Statistik (BPS). 2012. Produksi Kedelai Menurut Provinsi (ton), 1993 2015.

https://www.bps.go.id/linkTableDina mis/view/id/871

Badan Pusat Statistik (BPS). 2019. Impor Kedelai Menurut Negara Asal Utama, 2010-2019.

https://www.bps.go.id/statictable/20 19/02/14/2015/impor-kedelaimenurut-negara-asal-utama-20102019.html

Bahsan, Y. and de-Bashan, L. E. 2002. Protection of tomato seedlings against infection by Pseudomonas syringe pv. tomato by using plant growth promoting bacterium Azospirillum Brailense. Appl Environ Microbiol. 68(6): 2637-2643.

Day, J. M. and J. Dobereiner. 1976. Physiological Aspects of $\mathrm{N}_{2}$ fixation by Azospirillum from digitania roots. Soil Biol Biochem. 8: 45-50.

Jabbar, B. K. A. dan Halimi, M. S. 2012. Effect of molybdenum on biological nitrogen fixation by combination of Rhizobium and Azospirillum in soybean under drip irrigation system. International Journal of Life Sciences Biotechnology and Pharma Research Hyderabad. 1(2): 2250 - 3137.

Kirk, R. E. and D. F. Othmer. 1963. Kirk-Othmer Encyclopedia of Chemical Technology. John Wilet and Sons Inc. New York.

Nadiyah, Krisbiyanto dan A. Azizah. 2005. Kemampuan bakteri Acetobacter xylinum mengubah karbohidrat pada limbah padi (bekatul) menjadi selulosa. Bioscience, 2: 37-47. 
Nursyamsi, D. dan Suprihati. 2005. Sifat-sifat kimia dan mineralogi tanah serta kaitannya dengan kebutuhan pupuk untuk padi (Oryza sativa), jagung (Zea mays) dan kedelai (Glycine max). Bul. Agron. 33(3): 40 - 47.

Oedjijono, D. Ryandini, I.D.S.A.P. Permiarti. 2003. Formulasi Biofertilizer dari Kultur Campuran Bakteri Pemfiksasi Nitrogen dan Pelarut Fosfat pada Medium Onggok dan Dedak. Fakultas Biologi Unsoed, Purwokerto. [Laporan Penelitian]

Onifade, A.K. and Jeff-Agboola, Y.A. 2003. Effect of fungal infection on proximate nutrient composition of coconut (Cocos nucifera Linn) fruit. J. Food Agr Environ. 1(2): 141 - 142.

Paturau, J. M. 1982. By-Products of The Cane Sugar Industry. Elsevier Scientific Publishing Company. Amsterdam.

Palungkun, R. 2006. Aneka Produk Olahan Kelapa. Penebar Swadaya. Jakarta.

Prescott, L.M., J.P. Harley, and D.A. Klein. 2000. Microbiology. Ed ke-5. McGraw-Hill Companies, USA.

Pusat Penelitian Pengembangan Tanah dan Agroklimat (Puslitanak). 2003. Klasifikasi Tanah-Tanah di Indonesia. PPTA, Bogor.

Ray, J., L.G. Heatherly, and F.B. Fritschi. 2005. Influence of large amounts of nitrogen on nonirrigated and irrigated soybean. Crop Science. 46: 52-60.

Sison, B.C. 1977. Disposal of coconut processing waste. Philippine Journal of Coconut Studies. 2: $39-41$.

Soedarjo, M. 1997. Genetics of Mimosine Degradation by Rhizobium sp. Strain TAL1145 that Nodulates Leucaena spp. PhD. Dissertation, Dept. Microbiology of the University of Hawaii, 210 p.

Stella, D. and Sivasakthivelan, P. 2009. Effect of different organic amendments addition into Azospirillum bioinoculant with lignite as carrier material. Bot. Res. Intl. 2(4) :229 - 232.

Warisno. 2003. Budidaya Kelapa Genjah. Kanisius. Yogyakarta.

Widawati, S. 2015. Uji bakteri simbiotik dan nonsimbiotik pelarutan $\mathrm{Ca}$ vs $\mathrm{P}$ dan efek inokulasi bakteri pada anakan turi (Sesbania Grandiflora L. Pers.). Jurnal Biologi Indonesia 11 (2): 295-307. 